\title{
Human Security in Anthropology of Security Perspective: A Re-conceptualisation Attempt
}

\author{
Stanisław Jarmoszko \\ Department of Social Sciences, Siedlce University of Natural Sciences and Humanities, Siedlce, Poland \\ Corresponding author: stanislaw.jarmoszko@uph.edu.pl
}

Submitted: 2 May 2020 | In revised form: 13 August 2020 | Accepted: 1 October 2020 |

Published: 18 December 2020

\begin{abstract}
The article outlines the substantial frames of the anthropology of security as an independent anthropological (humanistic) sub-discipline and the anthropological approach to security. The multidisciplinary character of sources of the anthropological knowledge makes the anthropology of security a field of integration of biological and socio-humanistic facets of the knowledge of security aspects. The focus of the discipline is the entirety of human dispositions and accomplishments in the creation of the conditions for safe and satisfying existence, development and survival of both individuals and communities. Security, as well as the norms and patterns of human actions (i.e. cultural patterns of security) serving security creation, become the supreme category. Hence, the anthropology of security concentrates on the individual and collective natural protective and defensive dispositions (properties). Thus its attention focuses on creating technologies of security and the wholeness of the human artefacts stemming from their applications. In the anthropological perspective, security appears a sphere of creation and-simultaneously-its ultimate result. Therefore, it is more than a condition/process (a mere prelude to analyses). It is an intentionally created construction of human thought and an entity of practical activities. The presented reflections are only a broad, overall outline in both diachronic and synchronic areas. The aim of the article is to specify and promote an integrative approach in understanding the essence and structuring of the anthropology of security.
\end{abstract}

Keywords: anthropology of security; culture of security; human security; security anthropobiology

\section{Introduction}

The evaluation of contemporary academic or social security discourse shows that numerous analyses, particularly in macro-assessments (on national and international levels), lose the significance of an individual. This results in the emergence of the prevalent in the academic discourse and the applied practice, state-centred (and consequently politics- centred), paradigm of the security conceptualisation. Nevertheless, the primary reference of human security is an individual, and not a state. Throughout millennia, dramatic events concerning security have centred on individuals who were the subjects of fundamental generalisations on the simple-minded security shaping passed on in a generational, and then cross-ethnic, transmission. Within the prehistoric communities and cultures, certain security mechanisms had been created before any state structures developed. They culturally evolved and developed; some disappeared or were lost.

Understandably, human security (in the individual and 
collective dimensions) is - and should be-the interest of anthropology. It appears a most general and, simultaneously, a most comprehensive science on humanity; some claim it is a sort of an omniscience. The anthropological perspective, actually also comprising higher levels of human communities' lives, allows for the appropriate inclusion of an individual and - to a lesser degree-communities as the subject matter of science. In addition, it enables to look at the security issues in a different way, to balance all the levels, emphasise the security shaping mechanisms and stimulate the security process development. Anthropology provides the desired-primarily pragmatic-vision of the human and social security. It is especially important currently when an ordinary citizen's well-being is becoming a cardinal imperative of the state security policies as well as a priority of the supranational structures. The time of coronavirus pandemic is providing an additional aspect here.

\section{Premises of Anthropological Interest in Security Matters}

So let's look at why anthropology, generally understood, is (and should be) interested in human security matters. Contemporarily, the advance of the human security theory within the security research has become the core impulse for anthropologists to involve in security matters. The research concerns the issue particularisation, inquisitive analyses of the more specific (or fragmented) subjects in the increasingly explicit contexts and-thus-immersion in the security mechanisms. The "human security" concept concerns the security of ordinary individuals, population of specified areas or even the whole humanity in the populational dimension. "Human security" denotes the general risk categories associated with the proliferation of every possible threat/danger to humans (mass-scale included), e.g. famine, epidemics, natural and ecological disasters, wars, terrorism, religious and ideological conflicts, crime or the Internet hazards etc. [1-6]. "Human security" covers both individuals and communities; however, then it refers to the communities' aggregates and not structures which are rather described as societal or social security.

The initial interpretations assumed:

"The human security approach parallels the shift in economic development and international law from instrumental objectives (such as growth, or state rights) to human development and human rights [...] at a minimum human security can be determined by people's ability to be protected from the physical destruction of their lives and way of life. At its maximum it can mean a totally threat-free environment as defined by the peoples and communities themselves" ([7], pp. 5 and 90).

The United Nations' documents specify a number of material security components like economic, social, food, health, ecological or political (mainly human rights-oriented) security. Additionally, the personal and communal security is defined. It constitutes a substantial stress shift from the soulless state structures to living people and the whole humanity [8]. Such a process promotes the perception of security as the "security of people" rather than "security of formal state structures". Actually, the state security is not synonymic to the security of people inhabiting a country. Authoritarian and totalitarian systems provide abundant evidence that state security may be a direct source of threat/danger to common citizens.

The human security basic idea is the protection/security of individuals as well as the communities they constitute. Consequently, a secure state is a means of security for its citizens. The personal security, quality of life and human rights are the specifically protected values $[9,10]$. In such a case, a synergic combination of the national security and its human dimension becomes an appropriate approach. Still, a state itself may become an obstacle in security provision, especially when the state acts as a violator. To avoid such situations, according to the human security idea, it is advisable to support democracy development and activities of the international organisations entitled to the peaceful conflict-solving and humanitarian interventions [11,12].

T. H. Eriksen claims, "The term 'human security' has an important job to do in re-orienting social theory and building bridges between the different social sciences" ([13], p. 2). The anthropology of security plays the leading (even superior) role in the process. Anthropology as such-in its research perspective-combines three ultimate focal areas, i.e. humans, society and culture [14-18]. Hence, a thesis may be put forward that - with regard to social sciences and the humanities - anthropology serves a similar function to philosophy in reference to all sciences (the former Regina scientiarum). Although anthropology does not constitute the source of social sciences and humanities; unquestionably, it is a field of their integration. The science can be treated as a foundation for the integrated knowledge on humanity.

\section{The Significance and Contribution of Military Anthropology in the Development of Anthropology of Security}

Another prominent impulse to anthropology becoming involved in the security research was the emergence of the military anthropology stemming from the need to practically apply the anthropological knowledge to military purposes. Anthropology was said to become "armed", "militarised" or "militarily biased". In such a context, the pejorative term "mercenary anthropology" appeared and "litany of shame" started to be used in reference to anthropologists working for the military $([19,20]$, pp. 25-50). The conditions connected with the necessity to carry out the military operations, especially combating rebellions or uprisings in the administered areas of a culturally different nature constituted a direct catalyst for the "militarisation" of anthropology [21-23]. In such circumstances: "Anthropologists can come to have rich understandings not only of the people they live with but of the larger processes governing the warfare that desires to consume anthropological knowledge" ([24], p. 3).

The earlier wartime activity of anthropology was primar- 
ily connected with the production and provision of the expert knowledge necessary for military operations [25]. At the beginnings of the so-called War on Terrorism, more specifically with the US military engagement in Iraq and Afghanistan, the age of the "physical" anthropological participation in the military operations started. Its true evidence was the Human Terrain System's (HTS) activities. They were reinforcements of the military operations with the anthropological and social competences. The system created specialist teams (Human Terrain Teams-HTT) which-according to the makers: "gather information and include their recommendations on courses of action for the commander (...) assist the unit in preventing friction with members of the local population by identifying local dynamics, grievances and motivations, assessing governmental effectiveness and making recommendations on how to address them" ([26], p. 26).

Mapping Human Terrain (MAP-HT) procedures were commonly used in the HTTs operations.

In practice, HTS served the following five functions:

- "providing cultural advice and regional knowledge (including language skills) on site to military personnel in combat zones;

- populating non-classified, non-proprietary cultural databases maintained in the United States;

- cultural espionage; gathering clandestine cultural data for classified database,

- forensic anthropology; investigation of possible war crimes;

- preservation of valuable cultural patrimony in war zones" ([20], p. 142).

The military use of the anthropological knowledge, and anthropologists themselves, brought about serious controversies and protests within the academia. The rise of military anthropology, and the increasing recruitment and use of anthropologists in its various activities, has prompted a furious debate concerning the morality and academic or professional propriety of scholars working along, or otherwise providing assistance to, governments and their militaries in this fashion ([20], p. viii). At the end of 2006, the critics and supporters of the military application of anthropology created the Commission on the Engagement of Anthropology with the US Security and Intelligence Communities (CEAUSSIC) $[27,28]$. In a special report, three types of the anthropological military activities were examined:

1. anthropology of the military-comprising the anthropological studies of the military culture $\left(\mathrm{MA}_{1}\right)$;

2. anthropology for the military-comprising the Human Terrain System analysis $\left(\mathrm{MA}_{2}\right)$;

3. anthropology for the military-comprising educational programs (language, culture, regional studies) at military academies $\left(\mathrm{MA}_{3} ;\right.$ [20], p. 85).

The scientific recommendations concerning the military involvement of anthropology (as well as other social sciences) enforces the idea that science should not to be used to the human disadvantage. Hitler-time doctor Mengele commonly serves as a classic bad example in that context.
As a science, anthropology can study the objective phenomena of warfare and the military. However, it should not act against its cognitive research object.

Military anthropology does also find its supporters; especially in the context of the $9 / 11$ events. The term "anthropology in the securityscape" as a category of the socalled public (or: engaged) anthropology was created in that sense. Supporters of the term and approach claim that the anthropology of security is necessary not to defend or justify the militarily-involved anthropology, but to engage anthropology as such in important public matters [29-32].

M. McFate claims:

... "Initiative is urgently needed to incorporate cultural and social knowledge of adversaries into training, education, planning, intelligence, and operations. Across the board, the national security structure needs to be infused with anthropology, a discipline invented to support warfighting (...) Cultural knowledge of adversaries should be considered a national security priority"([33], p. 43).

Regardless the criticism of military anthropology (often fully justified), the challenge that modern anthropology seems to be facing "is not to question the possibility of using anthropology as a tool of destruction, but to determine the principles of its application" ([34], p. 616). Military anthropology does not merely serve destruction purposes; it contains a multitude of constructive factors. The broadly-understood issue of national security may be but a single example; still, competent ethical supervision is desirable.

It has to be openly stated the military anthropology deals with the theoretical and practical aspects of both offensive and defensive matters. The science-frequently and in an aware manner-takes up the security issues such as the security of own armed forces, natives, public places, historical monuments, transportation routes etc. Then, it is not only own troops' security that matters, but also the protection of the local communities and their culture in the war zone. Hardly is it surprising the military anthropology was a "midwife" of the anthropology of security.

\section{On the Essence of Anthropology of Security and its Place in the System of Science}

It is time to specify what the security of anthropology is. In recent years, despite the evident scarcity of anthropological description of security issues, as well as the lack of based foundations of the anthropology of security, there have appeared some harbingers of developmental invigoration, e.g. the first conferences, scientific specialisations, first scientific texts. They raise hope of a new, cognitively fascinating and practical discipline which may come into life. Initially theoretical but also increasingly empirical reflections mainly concerned the war in Iraq and Afghanistan, but also they referred to the practical use of the anthropologists in the military structures and operations [20,23,35-37]. Although the anthropological aspects of security were already pointed out in those early sources, they were all of rather initial or fragmentary nature as they related mostly to the 
organised scientific conferences or the Internet discourse [38-40]. Currently, the situation is radically more favourable. There are books and articles directly and literally dealing with the anthropology of security and investigating its problems [41-44]. There is an increasing number of sources thematically revolving around the anthropology of security.

Shaping its scientific identity, anthropology of security establishes its cognitive fields of interest, creates its specific techniques and methodology, develops its concepts and terms glossary and establishes certain relations with other sciences. Remaining in well-defined connections to physical and philosophical (even religious) anthropologies, the anthropology of security is-principally a category of socio-cultural anthropology (Figure 1) [45]. By nature, thus, it combines natural sciences with humanities [46].

Defining anthropology of security from perspective of cultural anthropology, dominant in most to-date considerations, does not reflect the whole essence of security problems. As it needs to face the necessities specific to that definite science, the anthropology of security does not always fit the classical anthropological tradition. Without considering human immunological system, psychological defensive mechanisms, protective and defensive behaviours, influence of family and social bonds, religious inspiration, generating and implementation of security (defensive) strategies on state level or social mobilisation etc., the proper comprehension of the sense of the human security seems impossible. Therefore, anthropology of security has to combine vari- ous threads, plots and scientific traditions. Human security, nonetheless, does not only rest upon the "cultural concept". Humans are neither exclusively biological beings nor solely cultural ones. Although any separation of the spheres is clearly false and the exclusion of either one is artificial, yet, sometimes it appears analytically needed and useful. Human bio-cultural nature is impossible to deny or question. Whatever collective security theoretical constructions one creates they ultimately refer to individuals, their general well-being, biological, psychological, social or spiritual conditions. Eventually, national, international, structural, institutional etc. security translates into individuals' security, their health and life. Ultimately, it is anthropocentric by nature.

Due to all the above, although the sub-discipline does base on the socio-cultural anthropology achievements, the anthropology of security cannot be reduced only to certain aspects of the socio-cultural anthropology. Human security has fundamental biological and psychosomatic foundations. Additionally, it has thorough philosophical and spiritual bases. Hence, by definition, if treated integrally, the anthropology of security must constitute a complex of various cognitive threads. They make up specific substantive components of the anthropological knowledge in security. Socio-cultural anthropology of security is one of the fundaments. Currently, it develops most intensively and appears most representative for the discipline.

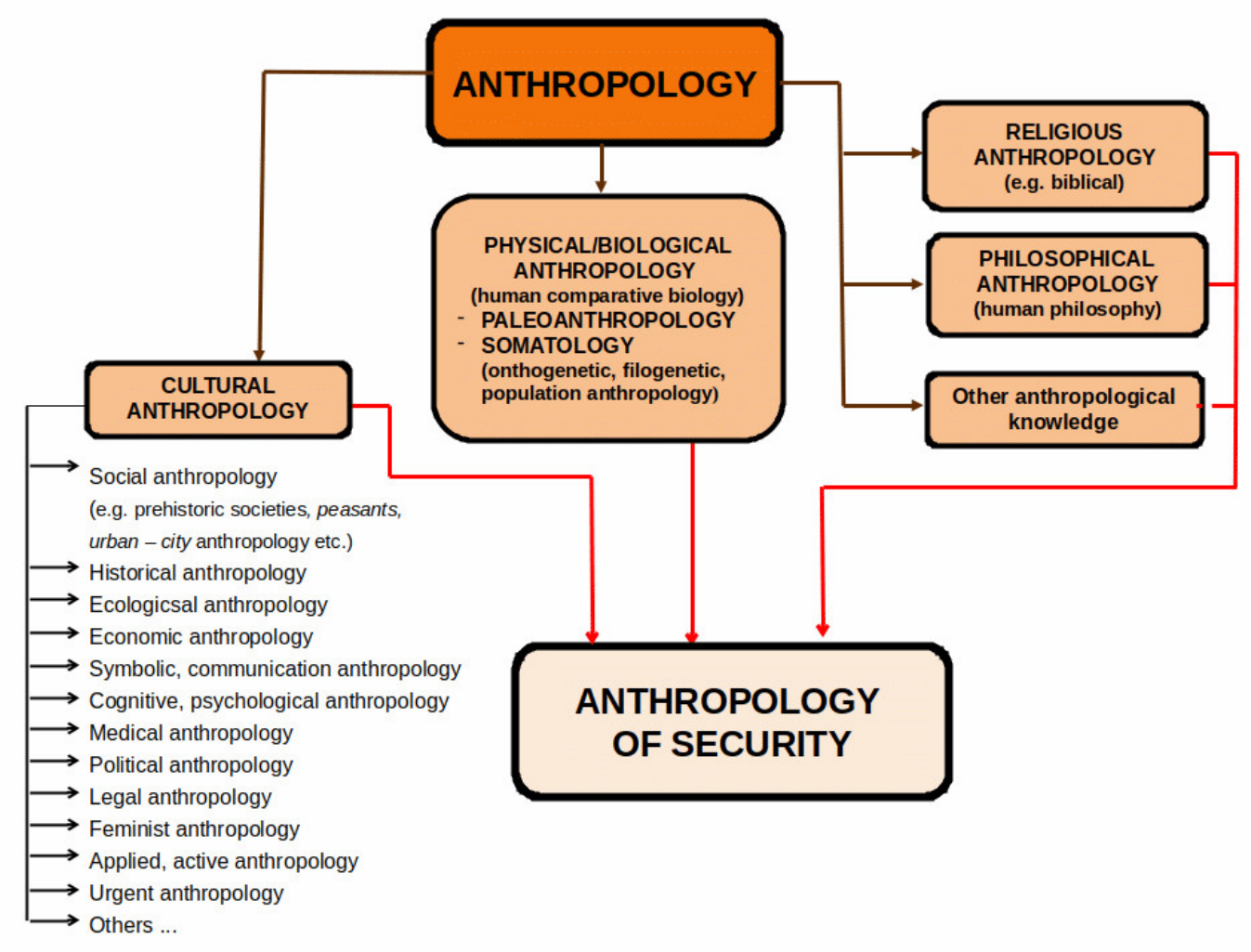

Figure 1. Anthropology of security among anthropological sciences. 
The biological anthropology of security seems equally vital. It makes the foundation for further cognitive research, which-remaining in an organic connection-contains the crucial substantive fields. Moreover, the philosophical anthropology of security can be distinguished which derives from human philosophy and completes it. Finally, there is the religious anthropology of security. It is connected with the religious anthropology; yet, it assumes its independence from the socio-cultural anthropology. They all enrich the narrations with the necessary and captivating contexts.

Obviously, the anthropology of security elements connected with other sources of anthropological knowledge (e.g. information technologies, robotics, transhumanism or $\mathrm{Al}$ ) are vital, too. All the listed threads, remaining in a complementary integration, complete the sense of the discipline. The holistically treated anthropology of security is also linked to the other fields of anthropology, significant for the security matters, even if they are oriented towards completely different questions, e.g. the anthropology of violence, war, peace, human rights, military, or combat [47-53]. Consequently, the most general understanding of the anthropology of security as a science includes general knowledge of human psychosomatic, human socio-cultural activities and cultural achievements in the context of security implementation towards oneself and others.

In synthesis, anthropology of security would not deserve its name, if it did not consider the biological human security factors including their spiritual and material complementation-located in the human culture and objective thinking. Focusing on the human thought and culture and ignoring the human biological constitution-human properties as a living, biological creature-would be a manifestation of incomplete considerations and misunderstanding of the human security. Needless to say, it would also be a scientific abuse. Only the integral approach does allow for the comprehensive multi-dimensional considerations of the human security as an individual, species and culture maker in one. A significant specific feature of the anthropology of security-compared to other sciences on security $[54,55]$ - is the stress shift from the state-centred perception of security to the anthropocentric one.

The subject of the discipline is the whole of the human dispositions and accomplishments in creating conditions ensuring safe and satisfying existence, development and survival of individuals and their natural communities. Security and representations of specific psychosomatic and behavioural dispositions, as well as norms and patterns of human actions (so-called cultural security patterns), alongside with the creations aimed at its making, appear the superior category. The cultural patterns develop within a given culture where people are forced to copy certain-necessary for them to survive-activities [56,57]. They become the outcome of the unaware choice canons. Security creation is fundamental for such behaviours. Thus, the cultural pattern, refers to a limited scale of human behaviour as normal and effective responses to a specific life situation.

In a specific sense, the complex history of mankind is a record of the making and implementation of the culture of security patterns. I understand the patterns as standards accepted by the society (or only locally-in their special agencies) as well behaviour and activities aiming at ensuring security to the entire society, certain groups, structures and individuals. They comprise thinking patterns, projections, implementations, communication and other manners of processing information in this respect. They also include petrified forms of mechanisms, prophylactic procedures and direct reactions. They embrace material, organisational, behavioural and spiritual elements, too. Those are shaped inter-subjectively, but constitute an epiphenomenon of every community.

Consequently, anthropology of security focuses on natural protective and defensive human properties (individual and collective alike). Most importantly, however, it aims at humans creating security-building technologies and the whole of human creations (artefacts) connected with their implementation, as an outcome of such a creation. Therefore, it refers to the biological aspects of humanity and the part of the human culture which co-creates the basic security realities and conditions.

In the introduction to the first monograph devoted to the anthropology of security (with its name in the title)-from the socio-cultural anthropology perspective-its authors claim:

... "Anthropologists have already made important contributions to understandings of security from the perspectives generated in diverse ethnographic research (...) a critical anthropology of security has far more potential, as already shown in exciting research that uses anthropological technics to explore secrecy, critical infrastructure protection and 'vital systems', bio-threats, and professional security expertise. There are also conceptual differences to be explored" ([58], pp. 8-9). They also point out security is a matter of life and death in the world's numerous conflicts zones and therefore it should become a subject of intense anthropological interest.

\section{Specificity of the Anthropological Understanding of Security}

Since security is the empirical and theoretical basis for the development of anthropology of security, at this point let us specify this concept more broadly from an anthropological point of view. As biological organisms and psychospiritual phenomena, humans cannot do without security. For years, social scientists-anthropologists, psychologists or sociologists-have been placing security within the system of human needs and treated it as the foundation of human biological, social and spiritual existence [59-64]. The irrational hope for full, ultimate security is a constant element of the human existence. Is it achievable? The human security is exceptional in nature as mankind is unique as a species. It is determined by the cultural dimension of humanity.

In the anthropological sense, security becomes not only an existential value, but also an attractive cognitive one: 
"Security is an anthropological space in its broad meaning, because it is a cultural concept (as a text and as a spaceterritory), and it is in this environment that the anthropologist of security should place himself in order not only to translate a reality, but to transpose it" ([65], p. 43). The understanding and communicating of the "security" term lay fundaments for the conceptualisation of the anthropology of security. Reviewing the definitions or stances commonly quoted in the literature, it is noticeable the sense of security can be encapsulated in a few brief statements. Still, security-as a comprehensive phenomenon - is broad and complex, largely owing to its multi-directional contexts. Hence, it requires deeper and larger narrations. For the clarity of thought, let us assume security is-in the most general, simplest and basic sense-a variable condition, a property of a specific object stemming from the lack of influence from threat/danger, which ensures satisfying existence, undisturbed functioning and development in a foreseeable perspective. Accordingly, it is a sound, positive and desirable condition.

The above-mentioned lack of influence from threat/danger may have twofold reasons. One is its real absence; the other would be efficacious protection against its negative outcomes. The first case (always limited by time and situation) is mainly of probabilistic nature. It is an outcome of coincidence, serendipity or luck. The latter is an effect of a-more or less conceptualised-planned action or effective protective response. It is closely connected with the capability of effective controlling one's life situation and efficient response to it. Here appears the room for anthropology to operate.

Security has become an object of interest of anthropology - the most general and holistic of the humanity sciences because it is conditio sine qua non of the human existence, comfort of living and-above all-survival. Curiously, security is also a fruit of human activity. From the anthropological viewpoint, security is a bio-cultural activity and creation; simultaneously, it is their result-the achieved conditions for the satisfying existence, development and survival of human beings [66-70]. Therefore, security is not a mere natural condition/process (which is just a springboard for further analyses); it is an intentional human creationbrought to life with the use of a whole range of specific artefacts. Security is a construct of human thought and practical activity. In the anthropological aspect, the description of the security idiosyncrasy merges with the emphasis on the activity which the state results from. In such a context, counter-acting or managing the threat/danger to the values can be pointed out. Even more so, the conviction of receiving rescue/help-interpersonal or social support-in a difficult or dangerous situation emerges as an additional criterion.

Although humans are social and cultural beings, they also remain biological creatures. Hence, they must satisfy their primary needs. Most generally, human basic needs can be understood dichotomously, both as self-survival prerequisites and species-survival requirements ([71], p. 96).
Both of those, aside ensuring the biological means to live, contain the requisite for the necessary dose of security. The biological root of the need for security directly corresponds with the so-called first biological law, which is to save life ([72], pp. 149 and 191). Once life ends, all the other contexts prove irrelevant. Disregarding the rare cases of the hunger for bravado and strong sensations ([73], p. 27), humans-by nature-look for certainty, continuity, maximum predictability, freedom, protection against threat/danger, survival etc. They search something well-known, acceptable, comfortable, peaceful, carefree, free of fears and real destructive threat or annihilation. The fundament of security refers to regular, calm and conflict-less life without fear, anxiety, grievances, victims or suffering. Therefore, it implies the necessity to achieve the (intentional creation of) biopsychical (even ontological) balance resting on the awareness of having the basic resources for existence, well-being and comfortable development.

In the classical A. H. Maslow's theory, security determines the basics of the human existence and is situated prominently within the pyramid of the human needs. In Maslow's view, the necessity of security is determined by the strife for stability, dependence, care, guardian support, freedom from fear, anxiety and chaos, need of structure, law, order, and constructive limitations etc [61]. Hence, security is an elementary, natural human necessity which determines the quality of existence and chances of survival and development. Contemporarily, such a stance is broadly accepted in social sciences.

Nevertheless, the need for security is peculiarly dualistic on different levels of analysis. On the one hand, it is about the objective dimension of the condition, ensuring the physical conditions for regular existence and functioning - thussurvival. On the other hand, it is about the subjective, psychical representation of the conditions, feeling of securitywhich may become autonomous and abstract from existing realities [74]. Another level of the mentioned dualism is the fact the need is of stricte biological provenance referring to the necessity to maintain physical inviolability and existence. Still, the requirement is of psycho-social nature and concerns the maintenance of psychical integrity (psychical comfort) in the confrontation with the social world.

The status of the need, in an obvious way, situates security among the human values. Security is an existential virtue and is among the top ten basic universal values, such as freedom, tolerance, justice, dignity, work, beauty, solidarity, truth and love. As it is a desired and-simultaneouslydeficit value, it should be pursued and carefully protected [75], pp. 208-209). On the one hand, it is a social, civilizational, cultural, political, economic, ecological etc. value. On the other, it is an existential-difficult to overestimate. Interestingly, it is a utilitarian merit serving the purpose of achieving other values (life, health, comfort, happiness etc.) which enable effective functioning and a good, dignified life. In that sense, security is also perceived as the supreme and natural human virtue. Additionally, it is categorised as the purpose of the human activity, even a mission. The 
existential ideal of security is perfectly illustrated by the witty, commonly-known aphorism by German general Klaus Naumann: "Security is not everything; still, without it, everything turns into nothing".

Security is multi-character, multi-dimensional and multifaceted; it also has various degrees of complexity [76,77]. It can be understood cross-sectionally as a state/condition, or-temporally - as a process. Security is a state in the situational sense-hic et nunc. However, considering security building, or its status in the human existence perspective, it must be perceived as a process. Since security is always a resultant of a combination of the elements constituting a certain situation, once they change, the security does change as well. Thus, in the process sense, the variable character of security is always burdened with a certain level of potentiality. In the psychological dimension, the inner and outer security can be determined, i.e. the objective security and individual sense of security. Obviously, the division into the inner and outer security applies to the social and state structures, too. It mainly refers to spotting potential threats/dangers.

The constructivist aspect of security, allows its interpretation as the passive and active security. The passive security stems from the conditions beyond the influence of the involved people. In such a case, an individual lives in an environment which is - in itself-safe for them; alternatively, their security is a result of efforts of others-without the individual's participation. It is the referential security then. The active security concerns the state which has been intentionally created. Man (individually or in co-operation with others) ensures their safe existence. In the course of development of the mankind, in order to survive, people constantly had to create not only certain security artefacts (material objects), but also techniques, methods, structures or mechanisms. The same happens in the humans' individual development. Having become of age, leaving the parental protective zone, an individual has to care for one's own security. Apart from having various gadgets supporting security, an individual needs to independently shape certain patterns of behaviour and activities to protect their security. In such an activity, in addition to one's own initiative, numerous hints can be received from the culture in which the individual lives and acts.

Principally, human security (both in its individual or collective dimensions) is subject focused. Its ultimate goal is the optimal life situation of a given person or human communities. Nonetheless, the object-based aspects, cannot be ignored. They are the areas of life which are peculiar spaces of human security. Attention drawn to the objectbased character of security was a result of the methodical security broadening - the fruit of theoretical approach to the matter. Its development was especially influenced by the progress of those state functions which were responsible for security (in the globalisation context). Those, in turn, ceased to be limited to the application of the military power [78-81]. The constant broadening of the substantive areas of security overlapping the economic, political, social, cul- tural, ecological and other matters needed reaching beyond the traditional manners of ensuring security.

The anthropological approach to security is based on its two essential properties, i.e. anthropocentrism and anthropogenesis of security. Anthropocentrism refers to security which is perceived from the perspective of human interest, everything which concerns people directly, or is connected with their well-being. Broadly speaking, it is about the security of the subject-based existence and functioning of individuals in their natural surroundings. Furthermore, as their security, people commonly treat the matters beyond their physical selves, e.g. the security of their grandchildren on a school trip, their country cottage, the general security/safety in their hometown, their country border security or even the security of the whole planet-always from the perspective of their own interest.

The anthropogenesis of security is analysed from the perspective of people as security providers (the concept already mentioned in the paper). All too often security is treated as a sui generis reality; it appears something which exists and happens on its own. In order to comprehensibly understand the sense of security, one needs to fully understand that human security is not an autonomous entity. It is always the state in which an individual currently is. It certainly is determined, to an extent, by the natural environment or coincidence; yet, above all, it is a human creation. The human history is a record of creating the whole system of objects, devices, buildings, institutions and organisations for safe environment of the human existence. The effects of this creation-with all the complexity-are the outcome of human genius and activity; consequently, they have become a part of the human culture. Simultaneously, they determined-and still do-the other areas of the broadly-understood cultural heritage of the human race.

\section{Anthropology of Security: Modelling the Paradigm}

The aim of this point is to specify the essence of anthropology of security as a relatively autonomous sub-discipline integrating knowledge about anthropological aspects of human security at various levels of human existence. Security is never granted permanently. Achieving security is a complex process. It consists of counter-acting (avoiding, preventing, opposing, combating) all sorts of real and potential threats/dangers. Broadly speaking, it stands on creating the conditions for undisturbed existence, functioning and development. In the anthropological perspective, biology and culture constitute the fundamental factors of the human survival, in the individual, community or species sense. The anthropobiology of security and culture of security are the foundations of security of individuals, communities and even species. The anthropobiology comprises of the physical [82-85], psycho-somatic and psychical [86-89] human security mechanisms, e.g. non-specific body defence, immunological and hormonal systems, pain, fear-anxiety, psychological defence etc. The culture of security encompasses the aggregate-material and immaterial mankind 
creation ensuring human security [90], e.g. people's ideas of security, projecting and preparatory intentions, patterns of behaviour, complex attempts at ensuring security while applying the necessary instrumentation.

Aside biology, it is culture that constitutes the vital component of human security. Once it appeared, a newsupra-organic-order of events was created. Culture, as a peculiar system, generates adequate protection, defence and attack mechanisms aimed at enemies threatening/endangering social integrity, the inner and outer ones alike. The activities are performed with the use of tools, weapons and various devices determining the form and content of such activities [60]. Hence, the culture guards the human security shaping the social system technology connected with a society and appropriately organised human activities.

People are-somehow naturally_predestined to action. Following A. Gehlen, action is the fundament of the anthropological distinction of the human race $[91,92]$. Thus, the comprehension of human activities (both physical-material and symbolic), their results and consequences in the field of security creation seem the basic imperatives of the anthropological approach to the security issues analysis. The humans are the main actor here; the security itself has its important constructivist aspect [93,94]-it constructs, to a various extent, the human thoughts and becomes the outcome of human work, the state which is - potentiallyhuman-created (either individually or in co-operation). People surround themselves with specific instruments, devices, mechanisms, methods and strategies of handling the surrounding threats/dangers. Those material and immaterial artefacts are defined as the culture of security.

As indicated in Figure 2, the human security is a function of three categories of human activities, which are in a direct relation to the above-outlined security instruments. Those are: 1) independent biological and psychological mechanisms guarding the psychosomatic well-being; 2) people's activities for their own use (the behaviosphere of security); 3 ) activity towards others, which is connected with using others' help (and output) noticeable in the whole myriad of other security spheres, beginning from the sociosphere of security.

L. A. Munarriz, a Spanish social anthropology professor, points at the four vital thematic areas of the anthropology of security: human security (individual dimension), public security (social dimension), cultural security (symbolic dimension), geopolitical security (territorial dimension) [95]. He sees security as a universal aspiration of humanity and the most precious social, multi-semantic weal. Hence, its analysis requires a multi-disciplinary approach, in which the anthropology of security should be most prominent.

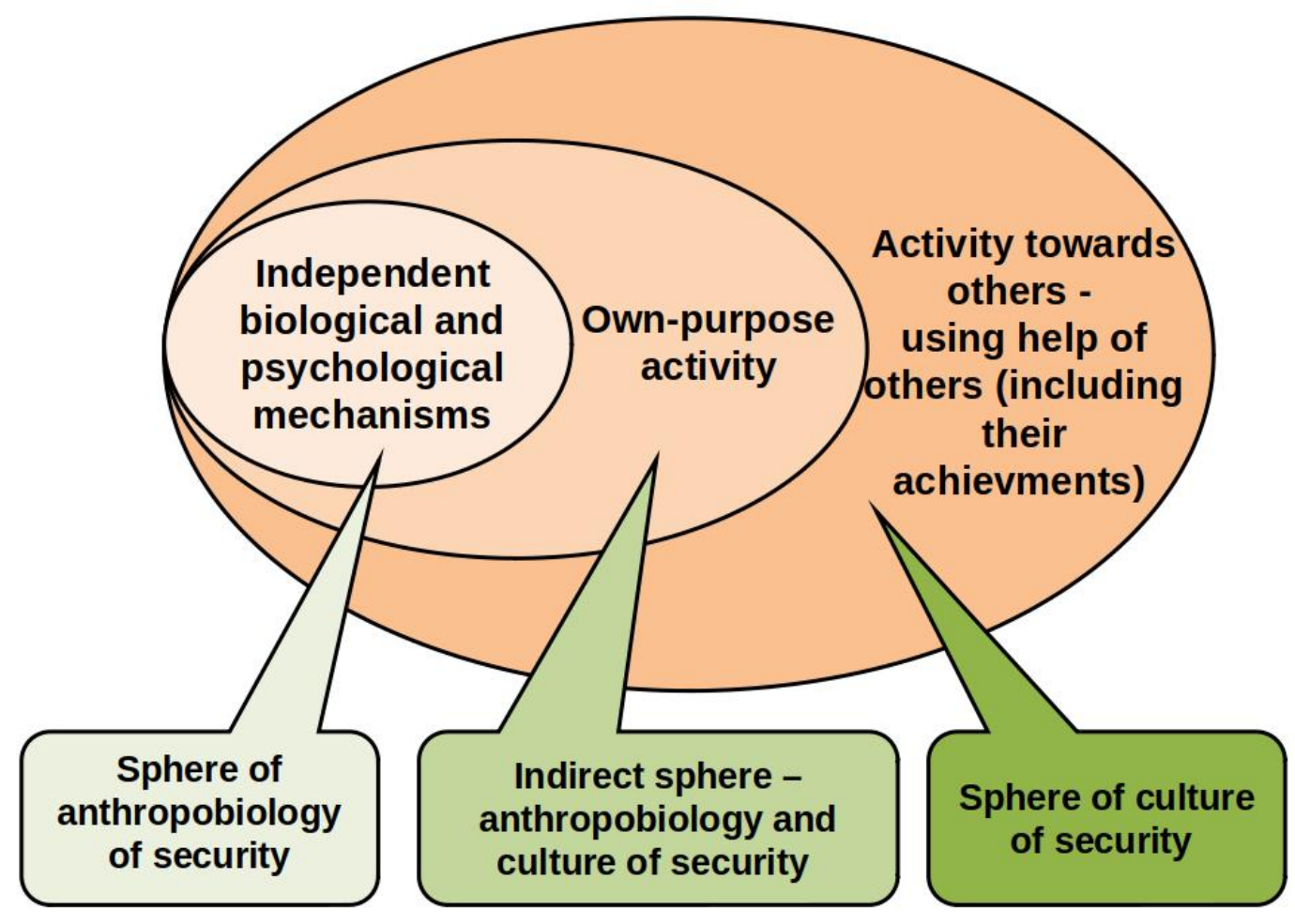

Figure 2. Human activity and security areas. 
Thus, the most general understanding of the anthropology of security encompasses the knowledge on human biology (psychosomatics), social activities and cultural output in the context of own and others' security creation-at present and in the past. Anthropology is equally focused on the past (diachronic approach) and on the presence (synchronic approach) of people as creators of security and the whole of their output in the field. The diachronic dimension of the anthropology of security consists of the analysis of the security shaping manners and effects in the various anthropological eras, thus, on the following stages of anthropogenesis and civilizational progress (prehistory, ancient times, Middle Ages, modern era, contemporary times). The diachronic perspective (literarily "throughout the time") characterises the process analysis in the perspective of the chronological chain of events [96]. Then, it is the anthropology of the history of security (Figure 3 ).

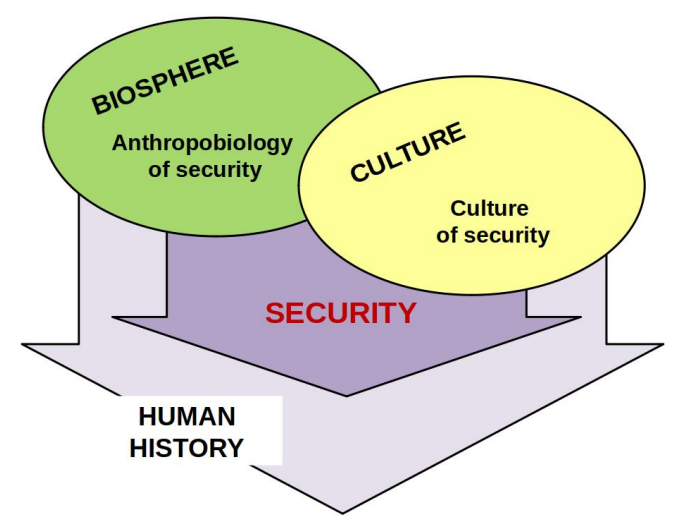

Figure 3. Human activity and security areas.

The synchronic approach concentrates on the mutual dependence and influence of the socio-cultural elements of a system aimed at the creation of security in the shorttime perspective, actually hic et nunc. The (structural and functional) inter-connections between or among the events and phenomena in the present (or in the nearest past, determined by the precise and narrow time frames) is emphasised. Much as the diachronic narration uses the linear thinking, the synchronic one rests on the systemic, pictorial and structural-functional reasoning. Obviously, both approaches remain in a close relation-the familiarity with the analysed system facilitates the inquisitiveness of the change analysis, whereas good orientation in the ongoing processes enables a detailed description of the system's condition.
The synchronic perspective emerges as the anthroposphere of security, peculiar technology of creating security of a given object (an individual or community) in all their object-based activities (e.g. health, psychological, social public, national, international, economic, ecological, information security and many more). The outlined premises allow a conclusion the anthroposphere of security has its direct reflection in the activities directed towards the creation, ensuring and maintenance of security of a given object. It is also the output of the activities (and technologies) in the form of a specific bio-psycho-techno-organisational mechanisms/system of security (including the whole collection of appropriate artefacts), remaining in the constant state of readiness for action-appropriate reaction and preventive operations. In the broadest sense, it is the culture of security. Additionally, it should be borne in mind the natural (commonly developed in an intentional way) human predispositions to the independent-oftentimes subconsciousprotection of one's bio-psychical side of their objectivityhuman security anthropobiology-remain the immanent part of the anthroposphere of security [46].

Since security is a considerably diverse and multifaceted phenomenon, the whole anthroposphere of security is complex and multi-layered. It consists of numerous areas-fragmented spheres. Therefore, two dimensions of analysis emerge naturally. The first is of subject-basedhierarchic nature and refers to the centre or holder, area and range of the security created. The other one, objectbased-substantive, differentiates the character of the space in which security is created (presented in Figure 4).

In the subject-based-hierarchic dimension, the anthroposphere of security-simultaneously-takes the concentric and hierarchic shapes. It is an entity determined by the character of the considered range in the respect of a given subject. Its crux is the optimal life situation of a given individual and human communities on various levels of integration. The anthroposphere of security encompasses the following hierarchic levels:

- personosphere of security: a human as an individual;

- sociostructuresphere of security: a community within a country;

- internatiosphere of security: regional relations between/among nations, states, international structures);

- globosphere of security: global structures applying to the whole world;

- cosmosphere of security: the systems reaching beyond the earth, space security systems creation. 


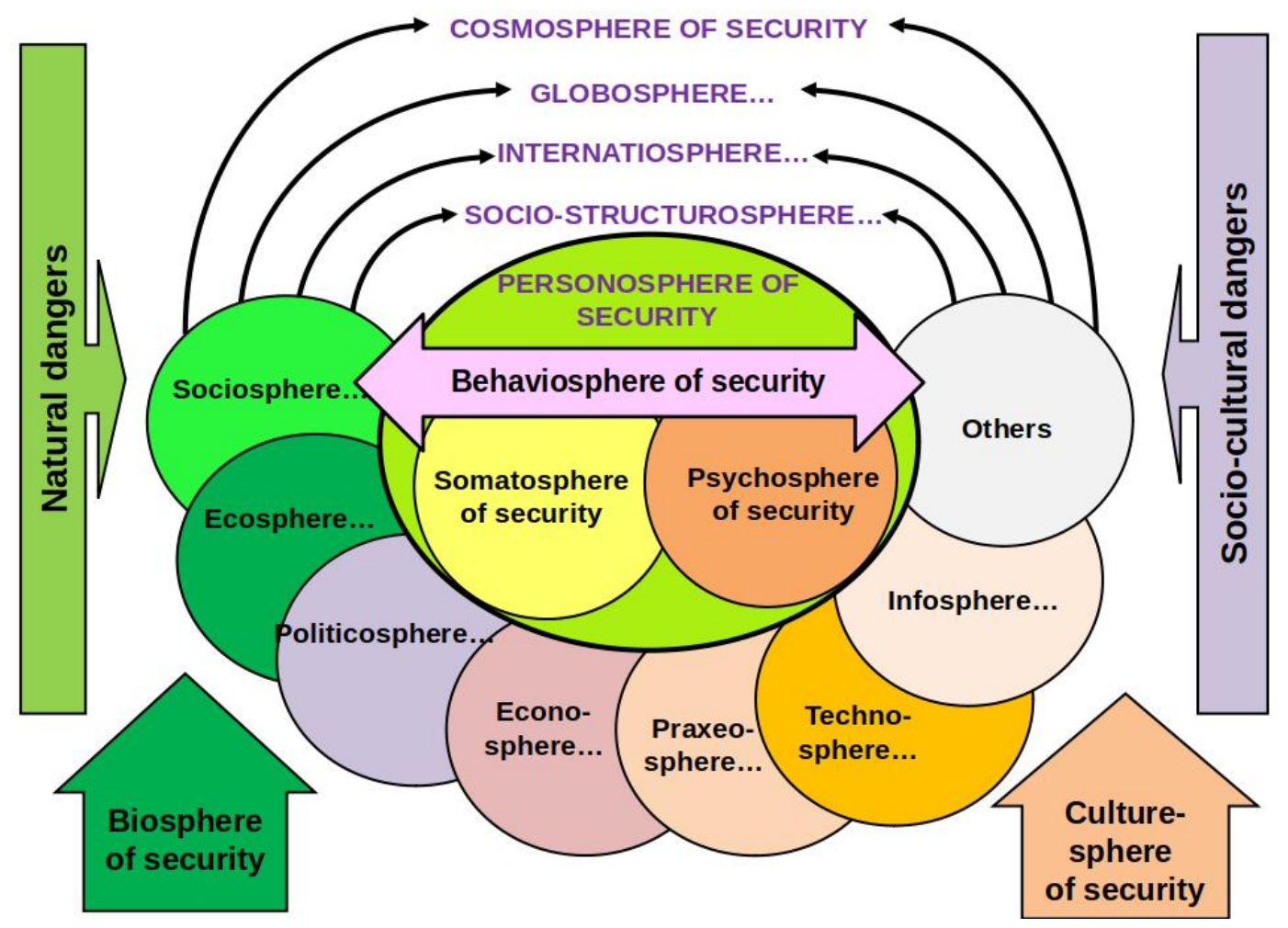

Figure 4. Anthroposphere of security: structure.

As every subject's security occurs in two spheres of life, the object-based-substantial dimension of the anthroposphere of security must also be considered. That dimension demonstrates in what areas and with the use of what means the anthroposphere executes its protective-defensive mission. The multi-dimensional character of the human nature as well as the reality of human life-in a natural mannerimplies complexity and physical multitude of the substantial spheres of human security, among others, such as:

- somatosphere of security: the vital, biological elements of the organism, e.g. elements of nonspecific protection, immunological or hormonal systems;

- psychosphere of security: the human psyche security elements, e.g. psychological defence, defensive mechanisms;

- behaviosphere of security: the art of adequate actions and behaviours in favour of one's own and others' security;

- sociosphere of security: social security mechanisms;

- ecosphere of security: biological or geological environmental elements securing the living organisms;

- technosphere of security: the application of technology to shape security;

- praxeosphere of security: the art of efficient action in the creation of security;

- econosphere of security: the use of the economic means to shape security;
- politicosphere of security: the use of the political instruments to shape security;

- infosphere of security: universal use of information in security shaping.

The listed spheres of security are situated in two main areas-the bio-sphere of security (natural security mechanisms) and culture-sphere of security (mechanisms and artefacts generated by the mankind).

\section{Anthroposphere of security in practice}

The outlined above anthroposphere of security structure could be now considered on the example of highly dramatic current situation that the humanity are facing because of COVID-19 pandemic outbreak. The first security mechanisms are situated in the somatosphere of security, primarily in immunological system mechanisms counteracting developing the infection. For instance, some people do not develop noticeable symptoms, moreover children display more resistance to it. The psychosphere of security is activated even in the hope for fast combating the infection or faith to avoid it while protective measures are taken. The behaviosphere of security is manifested mainly in practices aimed at preventing the infection, e.g. social distancing, wearing a face mask, proper hand hygiene. The sociosphere of security is manifested in the social support for medical services such as collective hand clapping at certain times on balconies to applaud health workers, concerts or cooking 
meals for medics by inactive restaurants, spontaneous initiative of sawing face masks, making hotel rooms available for people on quarantine, money raising (for hospitals, the unemployed or charities taking care of animals which lost their sources of income). The ecosphere of security actually contributes little in case of pandemic, unless we take as an example the biological and territorial isolation of people or the use of animals to test the vaccine.

All the above mentioned examples refer to the biosphere of security. The analysis of culturesphere will be started with the technosphere of security which gives the largest space for possible examples like the use of thermometers to measure the body temperature, application of medical technology (tests, respirators) as well as technologies to develop the vaccine or medicines and many others. The praxeosphere of security is connected with finding an effective strategy and then efficient implementation of procedures how to deal with infected patients (e.g. quarantine) and also the ability to avoid the infection. The idea of the politicosphere of security covers an effective crisis management of the state/society in the pandemic time (issuing acts of law, management of rescue and support services etc.). The econosphere of security refers to the use of economic measures in order to ensure conditions to combat the pandemic (the purchase of personal protective equipment, instruments, medicines) as well as economic support for these branches of economy which indirectly suffered from pandemic. The infosphere of security means diagnosing the patients, systematic media instructions how to behave in specific situations in order to avoid infection and also a large-scale campaign in media showing the development of pandemic in global and local scales.

The described spheres of security are located on different levels of subject- and hierarchy- oriented levels of security anthroposhere. The personosphere of security embraces everything what man does and what is at his disposal in his body and psyche so as to be protected against coronavirus. The sociostructuresphere of security covers all mechanisms, structures, institutions and devices that the state is equipped with in order to fight with pandemic. The internatiosphere of security is identified in international cooperation (in the regional scale) in combating the coronavirus outbreak (cross border regulations, offering help, coordination of activities e,g. return of people to their home country in case of the EU etc.). The globosphere of security also refers to the international cooperation but in the global, world scale (e.g. global exchange of information or WHO coordination of fight against pandemic). Due to the specific character of this threat it is difficult to observe the cosmosphere of security involvement in fighting the virus, but certainly it would be so in case of threat of an asteroid approaching the Earth. But that is a completely different topic.

\section{Conclusions}

Human security is a complex phenomenon, multi-faceted, multi-layered and multi-dimensional. Therefore, it cannot be thoroughly investigated by any single science or with the application of a single research approach. There emerges a conclusion on the multi-paradigmatic character of the anthropology of security. The security sciences themselves demonstrate such a nature. Having added to that the vast areas of the knowledge on the psychosomatic nature of people and the culture they have created, there emerges an immensely complex, multi-typical structure encompassing a myriad of theoretical and methodological approaches, orientations and research paradigms, methods and techniqueswith all the inter-disciplinary development facilities.

The article attempts at an integral presentation of the phenomenon. Humans are biological, social and cultural creatures; they process the surrounding world and themselves with the use of the increasingly sophisticated instruments and devices created with the application of science and technology. Simultaneously, people-due to their intellectual-cognitive capabilities and creativity-require a broad and varied cognition. A combination of natural sciences and humanities becomes a necessity. Then, the polytechnical elements come into play. The range of various disciplines' instruments application-determined by the level of cognition-does not deprive them of their autonomy; neither does it lead to their homogenisation. They are applied to perform specific cognitive tasks. The human knowledge consilience of evidence fully materialises through such an approach [97]. Thus, the space, instruments and technology of the human race security shaping are immanent elements of the anthropological paradigm as they are the basis of the anthropology of security. Obviously, the here-presented reflections are only the beginning of the considerations. It is a mere terminology pattern with the basic systemisation and structure.

The attractiveness of the anthropological perspective of security (either individuals or social communities of a smaller scale) rests on its distinct way of perception of the issues of security-balancing all the social life levels (personal life included). It also incorporates the mechanisms of security shaping and stimulating the initiatives to develop the process on various levels. The anthropology of security can be treated as a new opportunity to integrate the security problems, a sort of platform for combining the vital plots of safe life, functioning and development of the human communities' creation. Hence, the anthropology of security' is not just a mere new, multi-dimensional cognitive and praxeological perspective. The matters postulated in the paper-certainly far from complete-require further cognitive penetration and, simultaneously, an inter-disciplinary processing. 


\section{References and Notes}

[1] Carment D, Chen L, Fukuda-Parr S, Seidensticker E. Human Insecurity in a Global World. International Journal. 2005;60:880. doi:10.2307/40204079.

[2] Tadjbakhsh S, Chenoy AM. Human Security: Concepts and Implications. Taylor \& Francis Group; 2006. doi:10.4324/9780203965955.

[3] Goucha M, Crowley J. Rethinking Human Security. Wiley-Blackwell; 2008. doi:10.1002/9781444307290.

[4] Williams P. Security Studies: An Introduction. Routledge; 2008. doi:10.4324/9780203926604.

[5] Lautensach AK, Lautensach SW. Human Security in World Affairs: Problems and Opportunities. Caesarpress; 2013.

[6] Martin M, Owen T. Routledge Handbook of Human Security. Routledge; 2013. doi:10.4324/9781315885926.

[7] Eriksen TH, Bal E, Salemink O. World of Insecurity: Anthropological Perspectives on Human Security. Pluto Press; 2010. doi:10.2307/j.ctt183pcnn.

[8] Human Development Report 1994. Oxford, UK: United Nations-United Nations Development Programme; 1994. doi:10.18356/87e94501-en.

[9] Ogata S, Cels J. Human Security-Protecting and Empowering the People. Global Governance: A Review of Multilateralism and International Organizations. 2003;9(3):273-282. doi:10.1163/1942672000903002.

[10] Kaldor M. Human Security: Reflections on Globalization and Intervention. Polity Press; 2007.

[11] Gama C. Bridge over Troubled Waters: United Nations, Peace Operations and Human Security. Journal of Human Security. 2009;5(1):931. doi:10.3316/JHS0501009.

[12] Floyd R. Human Security and the Copenhagen School's Securitization Approach: Conceptualizing Human Security as a Securitizing Move. Human Security Journal. 2007;5(Winter):38-49.

[13] Eriksen TH. Human Security and Social Anthropology. In: Eriksen T, Bal E, Salemink O, editors. World of Insecurity: Anthropological Perspectives on Human Security. New York-London, USA-UK: Pluto Press; 2010. pp. 1-20. doi:10.2307/j.ctt183pcnn.

[14] Wolf ER. Anthropology. Prentice Hall; 1974.

[15] Hann C. Social Anthropology. McGraw-Hill; 2000.

[16] Barnard A. History and Theory of Anthropology. CUP; 2000. doi:10.1017/CBO9780511808111.

[17] Eriksen TH, Nielsen FS. A History of Anthropology. Pluto Press; 2013. doi:10.26530/oapen_625231.

[18] Hastrup K. Anthropology and Nature. Routledge; 2014. doi:10.4324/9780203795361.

[19] González RJ. Towards Mercenary Anthropology? Anthropology Today. 2007;23(3):14-19. doi:10.1111/J.1467-8322.2007.0021.x.

[20] Lucas Jr GR. Anthropologists in Arms: The Ethics of Military Anthropology (Critical Issues in Anthropology). Altamira Press; 2009.

[21] McFate M. Anthropology and Counterinsurgency: The Strange Story of their Curious Relationship. Military Review. 2005;85(2):24-38. Available from: http://usacac.army.mil/cac2/militaryreview/index.asp.

[22] Kelly JD, Jauregui B, Mitchell ST, Walton J. Anthropology and Global Counterinsurgency. University of Chicago Press; 2010. doi:10.7208/chicago/9780226429953.001.0001.

[23] Rubinstein R, Fosher K, Fujimura C. Practicing Military Anthropology: Beyond Expectations and Traditional Boundaries. Kumarian Press; 2013.

[24] Price DH. Weaponizing Anthropology: Social Science in Service of the Militarized State. CounterPunch-AK Press; 2011.

[25] Benedict R. The Chrysanthemum and the Sword: Patterns of Japanese Culture. Houghton Mifflin Harcourt; 1946. A symptomatic example was Ruth Benedict the analytical-advisory work written on order of the US authorities. Its aim was to present the specifics of the Japanese culture (for the use of the winners-to-be). The writing's outline was a complete book "The Chrysanthemum and the Sword: Patterns of Japanese Culture". The book was supposed to simplify the American military and politicians in their activities, at the same time helping them understand the defeated ones. Most curiously, the authoress herself never visited Japan.

[26] Finney N. Human Terrain Team Handbook. Fort Leavenworth; 2008.

[27] Final Report. American Anthropological Association, Com- mission on the Engagement of Anthropology with the US Security and Intelligence Communities; 2007. Available from: http://s3.amazonaws.com/rdcms-aaa/files/production/public/ FileDownloads/pdfs/pdf/FINAL_Report_Complete.pdf.

[28] Final Report on The Army's Human Terrain System Proof of Concept Program; 2009. doi:10.31037/e621329011-001.

[29] Wax ML. Wartime Dilemmas of an Ethical Anthropology. Anthropology Today. 2003;19(3):23-24. doi:10.1111/1467-8322.00194.

[30] Albro R. Anthropology's Terms of Engagement With Security. Anthropology News. 2007;48(January). doi:10.1525/an.2007.48.1.20.

[31] Goldstein DM. Security and the Culture Expert: Dilemmas of an Engaged Anthropology. PoLAR: Political and Legal Anthropology Review (Supplement). 2010;33(1). doi:10.1111/j.15552934.2010.01071.x

[32] Marcus GE. Conclusion: "Be All That You Can Be...": The Anthropological Vocation in the Securityscape. In: Albro R, Macus G, McNamara L, Schoch-Spana M, editors. Anthropologists in the Securityscape. Ethics, Practice, and Professional Identity. Left Coast Press; 2016. pp. 245-258. doi:10.4324/9781315434810.

[33] McFate M. The Military Utility of Understanding Adversary Culture. Joint Force Quarterly. 2005;38:42-48.

[34] Kowalski MW. Antropolodzy na wojnie. O „brudnej” użyteczności nauk społecznych [Anthropologists at War. On the "Dirty" Usage of Social Sciences]. WUW; 2015. doi:10.31338/uw.9788323516149.

[35] Selmeski BR. Who are the Security Anthropologists? Anthropology News. 2008;48(5):11-12. doi:10.1525/an.2007.48.5.11.2

[36] Griffin M. An Anthropologist among the Soldiers. In: Kelly J, Jauregui $\mathrm{B}$, Mitchell S, J W, editors. Anthropology and Global Counterinsurgency. University of Chicago Press; 2010. pp. 215-229. doi:10.7208/chicago/9780226429953.001.0001.

[37] Albro R, Marcus GE, McNamara LA, Schoch-Spana M. Anthropologists in the Securityscape. Ethics, Practice, and Professional Identity. Left Coast Press; 2016. doi:10.4324/9781315434810.

[38] Ferguson R. The Challenge of Security Antropology. In: SAR Seminar "Scholars, Security, and Citizenship". Newark, NJ, USA: Rutgers University; 24-25 July 2008. pp. 1-44.

[39] Postill J. Towards an Anthropology of Security. Call for Papers for a Special Session at the 2010 Annual Conference of the Canadian Anthropological Society. Via Cascanews. 2010; February.

[40] Spencer J. The Perils of Engagement. A Space for Anthropology in the Age of Security? Current Anthropology. 2010;51(s2):289-299. doi: $10.1086 / 653421$

[41] Goldstein DM. Toward a Critical Anthropology of Security. Current Anthropology. 2010;51(4):487-517. doi:10.1086/655393.

[42] Cabalza CB. The Anthropology of National Security. In: The Study of National Security at 50: Re-awakenings. National Security Rewiew NDCP; 2013. pp. 69-83. Available from: http://www.ndcp.edu.ph/wpcontent/uploads/publications/re-awakeningat50ndcp.pdf.

[43] Jarmoszko S. U źródeł naukowej tożsamości antropologii bezpieczeństwa [At the root of Scientific Identity of Anthropology of Security]. In: Cieślarczyk M, Filipek A, Świderski A, Ważniewska J, editors. Elementy teorii i praktyki transdyscyplinarnych badań problemów bezpieczeństwa [Elements of the Theory and Practice Transdisciplinary Research Security Issue]. UPH Siedlce; 2013. pp. 53-82.

[44] Maguire M, Frois C, Zurawski N. The Anthropology of Security: Perspectives from the Frontline of Policing, Counter-terrorism and Border Control. Pluto Press; 2014. doi:10.2307/j.ctt183p3j7.

[45] Barnard A, Spencer J. Encyclopedia of Sacial and Cultural Anthropology. Routledge; 2002. doi:10.4324/9780203458037. There are also other ways of structuring anthropology. E.g., in the American tradition, the so-called the "perspective of four fields of academic tradition" was established. It is a classification placing within anthropology (perceived holistically) biological and cultural anthropology as well as archeology and anthropological linguistics.

[46] Jarmoszko S. Antropologia bezpieczeństwa. Kontury naukowej tożsamości [Anthropology of security. An Outline of Scientific Identity] Uniwersytet Przyrodniczo-Humanistyczny w Siedlce; 2015.

[47] Parkin D. The Anthropology of Evil. Blackwell; 1985

[48] Turner PR, Pitt D. The Antropology on War and Peace: Perspectives on the Nuclear Age. vol. 5. Greenwood Press; 1989. doi:10.1525/ae.1990.17.3.02a00130.

[49] Messer E. Anthropology and Human Rights. An- 
nual Review of Anthropology. 1993;22(1):221-249. doi:10.1146/annurev.an.22.100193.001253.

[50] Schmidt B, Schröder IW. Anthropology of Violence and Conflict. Routledge; 2001. doi:10.4324/9780203451861.

[51] Stomma L. Antropologia wojny [Anthropology of War]. Iskry; 2014.

[52] Boulding E. Peace Culture: The Problem of Managing Human Difference. Cross Currents. 1998;48(4):445-457. Available from: http://www.crosscurrents.org/boulding.html.

[53] Turay TM, English L. Toward a Global Culture of Peace. Journal of Transformative Education. 2008;6(4):286-301. doi:10.1177/1541344608330602.

[54] Smith CL, Brooks DJ. Security Science: The Theory and Practice of Security. Elsevier; 2013. doi:10.1016/b978-0-12-394436-8.0000.

[55] Wróblewski R. Wprowadzenie do nauk o bezpieczeństwie/Introduction to Security Science. Uniwersytet PrzyrodniczoHumanistyczny w Siedlce; 2017. Available from: https: //ksiegarnia.pwn.pl/Wprowadzenie-do-nauk-o-bezpieczenstwie, 789359712, p.html.

[56] Benedict R. Patterns of Culture. Routledge; 2019. doi:10.4324/9780429054419.

[57] Linton R. The Cultural Background of Personality. Routledge; 1998.

[58] Maguire M, Frois C, Zurawski N. Introduction. The Anthropology of Security: Prospects, Retrospects and Aims. In: Maguire M, Frois C, Zurawski N, editors. The Anthropology of Security: Perspectives from the Frontline of Policing, Counter-terrorism and Border Control. Pluto Press; 2014. pp. 1-23. doi:10.2307/j.ctt183p3j7.6.

[59] Wulsim FR, Cattell RB. A Revaluation of Our Civilization. Argus Press; 1944.

[60] Sellars RW, McGill VJ, Farber M. Philosophy for the Future. MacMillan Company; 1949.

[61] Maslow AH. Motivation and Personality. Harper and Row; 1954.

[62] Hall ET. The Silent Language. Anchor; 1973. Available from: https://monoskop.org/images/5/57/Hall_Edward_T_The_ Silent_Language.pdf.

[63] Douglas M. Purity and Danger: An analysis of Concepts of Pollution and Taboo. Routledge; 1966.

[64] Holbraad M, Pedersen MA. Times of Security: Ethnographies of Fear, Protest and Future; 2013. doi:10.4324/9780203077856.

[65] Hurtado FA, Ercolani G. Anthropology and Security Studies. Universidad de Murcia-Nottingham Trent University-College of William and Mary; 2013.

[66] Blatz WE. Human Security: Some Reflections. University of Toronto Press; 1966. doi:10.3138/9781442632134.

[67] Bloomfield HH, Cooper RK. How to be Safe in an Unsafe World: The Only Guide to Inner Peace and Outer Security. Crown; 1997.

[68] McIntosh D. Human, Transhuman, Posthuman: Implications of Evolution-by-design for Human Security. Journal of Human Security. 2008;4(3). doi:10.3316/jhs0403004.

[69] Lakoff A, Collier S. Biosecurity Interventions: Global Health and Security in Question. Columbia University Press; 2008. doi:10.7312/lako14606

[70] Bajc V, de Lint W. Security and Everyday Life. Routledge; 2011. doi:10.4324/97802038332523.

[71] Obuchowski K. Psychologia dążeń ludzkich [Human Aspirations Psychology]. PWN; 1983

[72] Kępiński A. Lęk [Anxiety]. PZWL; 1987.

[73] Zuckerman M. Behavioral Expressions and Biosocial Bases of Sen- sation Seeking. CUP; 1994

[74] Frei D. Sicherheit: Grundfragen der Weltpolitik [Security: fundamental questions and world politics]. Verlag W. Kohlhammer; 1977.

[75] Lipiec J. Świat wartości [The World of Values]. FALL; 2001.

[76] Stańczyk J. Formułowanie kategorii pojęciowej bezpieczeństwa [Formulating the Term Categories of Security]. FNCE; 2017.

[77] Wróblewski R. Bezpieczeństwo narodowe. Zintegrowane i zrównoważone [National Security. Integrated and Sustainable]. UPH Siedlce; 2019.

[78] Fischer D. Non-military Aspects of Security: A Systems Approach. Dartmouth Publishing; 1993.

[79] Rothschild E. What is Security? Daedalus. 1995;124(3):53-98. Available from: https://www.jstor.org/stable/20027310.

[80] Buzan B, Waever O, de Wilde J. Security: A New Framework for Analysis. Rienner, Lynne; 1998.

[81] Battersby P, Siracusa JM. Globalization and Human Security. Rowman and Littlefield Publishers; 2009.

[82] Lydyard P, Whelan A, Fenger M. Bios Instant Notes: Immunology. Taylor \& Francis Group; 2009. doi:10.4324/9780203808306.

[83] Abrahams P. The Atlas of the Human Body. Bright Star Publishing; 2002.

[84] Clancy J, McVicar A. Physiology and Anatomy: A Homeostatic Approach. Arnold; 2002.

[85] Sompayrac L. How the Immune System Works. Wiley-Blackwell; 2012.

[86] Freud A. The Ego and the Mechanisms of Defence. Taylor \& Francis; 2018. doi:10.4324/9780429481550.

[87] Vaillant GE. Ego Mechanisms of Defence. American Psychiatric Press; 1992

[88] Conte HR, Plutchik R. Ego Defenses: Theory and Measurement John Wiley; 1995.

[89] Cramer P. Protecting the Self: Defence Mechanisms in Action. Guilford Press; 2006.

[90] Cieślarczyk M. Kultura bezpieczeństwa i obronności/Defence and Security Culture. AP Siedlce; 2007.

[91] Gehlen A. Der Mensch. Seine Natur und seine Stellung in der Welt. Athenäum; 2009.

[92] Gehlen A. Anthropologische und sozialpsychologische Untersuchungen [Anthropological sociopsychological research]. Rowohlt Verlag; 1986.

[93] Newman E. Human Security and Constructivism. International Studies Perspectives. 2001;2(3). doi:10.1111/1528-3577.00055

[94] McDonald M. Constructivism. In: Williams P, editor. Security Studies: An Introduction. Routledge; 2008. pp. 59-72. doi:10.4324/9781315228358-4.

[95] Álvarez Munarriz L. Foreword. Anthropological Approach to Security. In: Hurtado F, Ercolani G, editors. Anthropology and Security Studies. Universidad de Murcia-Nottingham Trent University-College of William and Mary; 2013. pp. 5-14. Available from: https://researchingsecurity.files.wordpress.com/2013/10/bookanthropology-and-security-studies.pdf.

[96] Jarmoszko S. Za kulisami przetrwania. Diachroniczna perspektywa antropologii bezpieczeństwa [Behind the Scenes of Survival. Diachronic Perspective of the Anthropology of Security]. UPH Siedlce; 2019.

[97] Wilson EO. Consilience: the Unity of Knowledge. Vintage Books; 1999. 